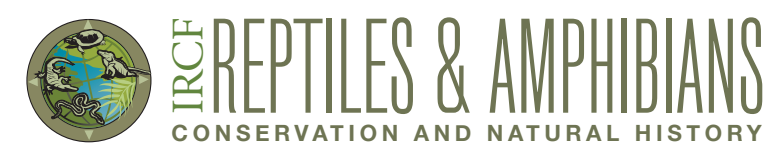

\title{
First Appearance of the Brahminy Blindsnake, Virgotyphlops braminus (Daudin 1803) (Squamata: Typhlopidae), in North America, with Reference to the States of Mexico and the USA
}

Van Wallach

4 Potter Park, Cambridge, MA 02138, USA (serpentes1@comcast.net)

$\mathrm{T}$ he Brahminy Blindsnake (Virgotyphlops braminus; Figs. $1 \& 2$ ) is the smallest and most widely distributed vertebrate, the most successful invasive herpetological species, and the most frequently introduced parthenogenetic reptile in the world (Bomford et al. 2009; Grace and Grace 2015; Mahoney et al. 2015). It has now reached at least 118 countries and island territories on every continent (except South America and Antarctica) and inhabits no fewer than 543 islands (Wallach 2020a).

Some 15 years passed from the first observation and collection of the little Indian snake, which Russell (1796) called the Rondoo Talooloo Pam, until it was formally described and christened Eryx braminus by Daudin (1803). Another quarter century passed before Cuvier (1828), realizing that boids and scolecophidians were not related, transferred braminus to the genus Typhlops, where it remained for nearly 140 years until Robb (1966) established Ramphotyphlops for the Australasian typhlopids with eversible hemipenes and retrocloacal sacs.

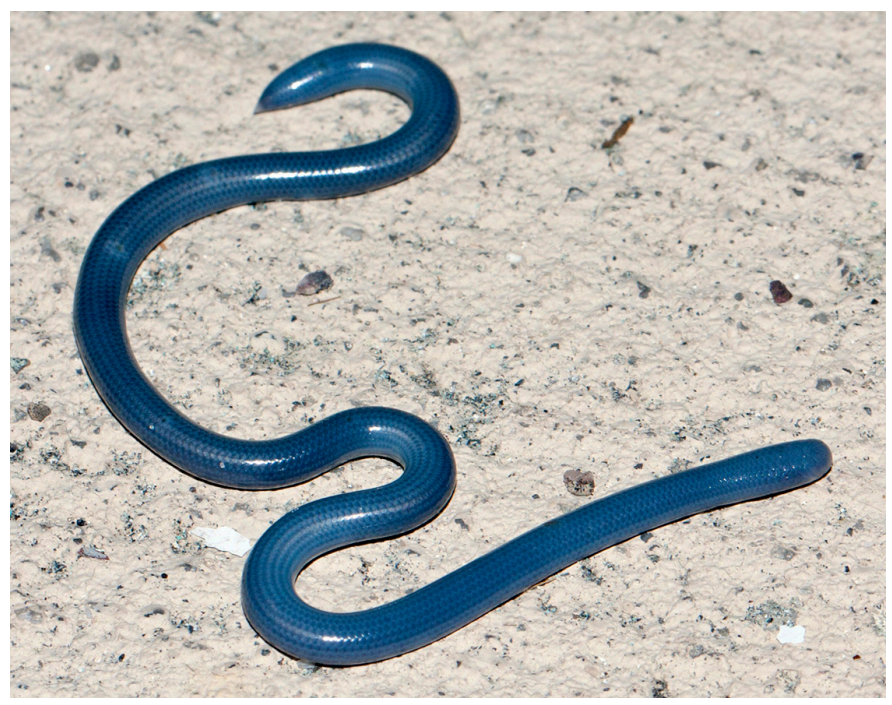

Fig. 2. A Brahminy Blindsnake (Virgotyphlops braminus) from Seminole, Pinellas County, Florida. This snake is about to shed, which accounts for the blue-gray coloration. Photograph by Kenneth L. Krysko.
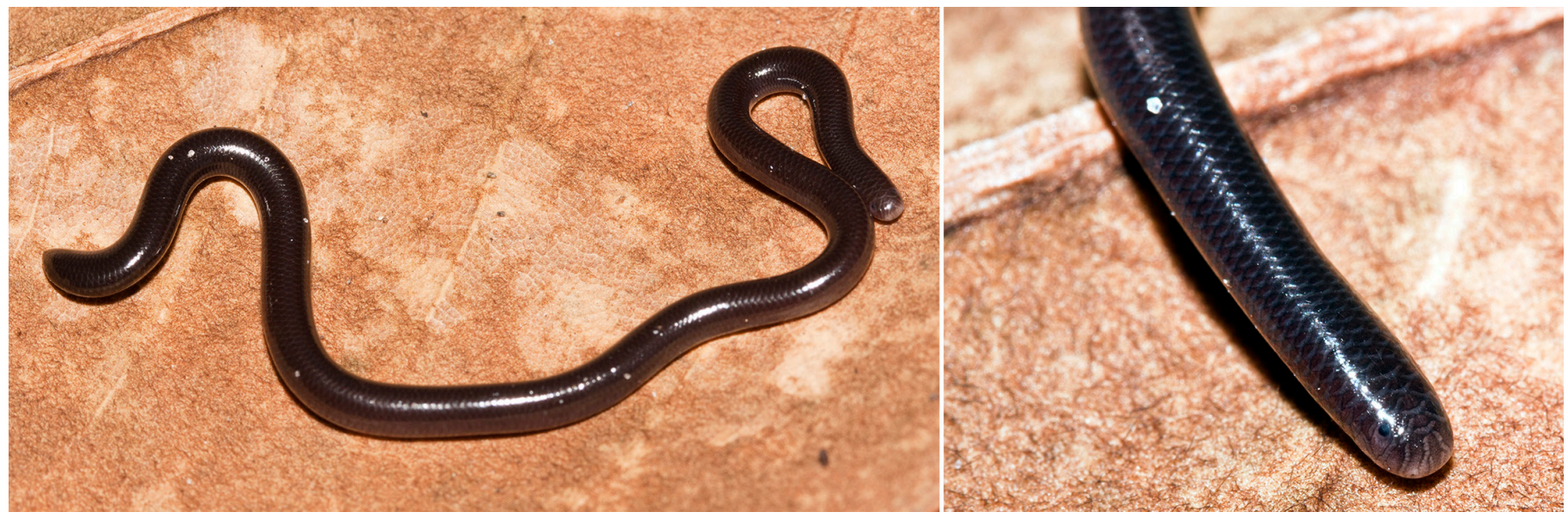

Fig. 1. A Brahminy Blindsnake (Virgotyphlops braminus) from Port St. Lucie, St. Lucie County, Florida. Photographs by Kenneth L. Krysko. 
Lack of hemipenial data for braminus resulted in its transference to Ramphotyphlops based on geography. Only eight years later, McDowell (1974) transferred braminus to Typhlina based on an earlier synonym for Ramphotyphlops, but it reverted back to Ramphotyphlops when it became known that Typhlina was a preoccupied genus (Williams and Wallach 1989; Wallach 2009). The molecular study of Hedges et al. (2014), which broke up the cosmopolitan genus Typhlops into numerous genera, resulted in braminus becoming Indotyphlops braminus. Most recently, Wallach (2020b) transferred braminus to a newly created genus Virgotyphlops in recognition of its obligate parthenogenetic nature.

The data collected for the two tables summarizing the invasions of Mexico and the USA by Brahminy Blindsnakes emanated from four types of sources: the primary literature, natural history collections, online databases, and social media. A complete listing of sources is in Wallach (2020c). Museum acronyms follow Wallach et al. (2014) except for:

Table 1. Data on the invasion of México by Brahminy Blindsnakes (Virgotyphlops braminus) arranged chronologically from earliest to latest appearance. Columns contain the state, followed by the known minimum (Min.) and maximum (Max.) elevation in meters, the first date it was observed or reported, the earliest known museum voucher, and the reference of its first verified publication.

\begin{tabular}{|c|c|c|c|c|c|}
\hline \multirow[b]{2}{*}{ State } & \multicolumn{2}{|c|}{ Elevation } & \multirow{2}{*}{$\begin{array}{l}\text { First } \\
\text { Date }\end{array}$} & \multirow{2}{*}{$\begin{array}{l}\text { Earliest } \\
\text { Voucher }\end{array}$} & \multirow{2}{*}{$\begin{array}{l}\text { First } \\
\text { Publication }\end{array}$} \\
\hline & Min. & Max. & & & \\
\hline Guerrero & 12 & 2,159 & 1891 & ZMUC 52172 & Shreve 1938: 144 \\
\hline Michoacán & 22 & 1,900 & 1913 & BMNH 1914.1.28.120-1 & Smith and Taylor 1945: 19 \\
\hline Sinaloa & 0 & 389 & 1961 & UCLA 14693 & Campbell and Howard 1962: 202 \\
\hline Baja California Sur & 19 & 123 & 1963 & BYU 22441 & Murphy and Ottley 1979: 119 \\
\hline Morelos & 1,015 & 2,620 & 1965 & FMNH 154799 & Dixon and Hendricks 1979: 36 \\
\hline Querétaro & 757 & 1,920 & 1971 & SAM 1185 & Cervantes and Minton 1975: 117 \\
\hline Jalisco & 11 & 2,414 & 1991 & UNAM-MZFC 4754 & Dundee and Flores-Villela 1991: 26 \\
\hline Veracruz & 0 & 1,426 & 1993 & MZFC 5480 & Mendoza-Quijano et al. 1993: 110 \\
\hline Oaxaca & 24 & 2,015 & 1993 & UNAM-MZFC 6009 & Mendoza-Quijano et al. 1994: 34 \\
\hline Puebla & 1,236 & 2,150 & 1993 & EBUAP 930033 & Eliosa-León et al. 1995: 110 \\
\hline Aguascalientes & 1,550 & 1,900 & 1993 & UAA-VR 254 & Vázquez-Díaz and Quintero-Díaz 2001: 279 \\
\hline Nuevo León & 361 & 909 & 1995 & ENCB-IPN & Alvarez and Murillo 1996: 1-2 \\
\hline Distrito Federal & 2,249 & 2,376 & 1995 & IBH 11281 & Mancilla-Moreno and Ramírez-Bautista 1998: 54 \\
\hline San Luis Potosí & 127 & 1,874 & 1996 & IIZD 206 & Campillo-García 2013: 26, 40 \\
\hline México & 1,740 & 2,367 & 1997 & IBH 11307 & Valdespino and García-Collazo 2000: 186 \\
\hline Quintana Roo & 5 & 20 & 1998 & ECO-CH-H 530 & Cedeño-Vázquez et al. 2003: 394 \\
\hline Durango & 1,125 & 1,928 & 1999 & CIIDRUD 502-3, 535 & Guzmán and Muñiz-Martínez 1999: 2 \\
\hline Tamaulipas & 82 & 427 & 2004 & UTA 53054 & Farr et al. 2013: 635 \\
\hline Campeche & & 3 & 2005 & UNAM-MZFC 18282 & Solano-Zavaleta et al. 2006: 500 \\
\hline Nayarit & 8 & 612 & 2007 & UNAM-MZFC 6148-9 & Quijada-Mascareñas and Canseco-Marquez 2007: 490 \\
\hline Sonora & 229 & 1,194 & 2007 & UNAM-MZFC 6147 & Quijada-Mascareñas and Enderson 2007: 490 \\
\hline Tabasco & 7 & 19 & 2007 & INIRENA 678 & Paz-Gutiérrez et al. 2008: 373 \\
\hline Hidalgo & 1,308 & 1,930 & 2008 & CIB 2346 & Hernández-Salinas and Ramírez-Bautista 2010: 519 \\
\hline Yucatán & 4 & 23 & 2009 & MCZ Herp. Obs. 27 & Paradiz-Domínguez 2016: 630 \\
\hline Chiapas & 117 & 184 & 2010 & MCBFESI 254 & Hernández-Ríos and Trejo-Perez 2010: 622 \\
\hline Chihuahua & & 1,440 & 2015 & SDSNH-PC 5274-6 & Carbajal-Márquez et al. 2015: 573 \\
\hline Baja California Norte & 9 & 104 & 2015 & UABC 2205 & Valdez-Villavicencio et al. 2016: 205 \\
\hline Zacatecas & & 1,902 & 2015 & SDSNH-PC 5301 & Bañuelos-Alamillo and Carbajal-Márquez 2016: 204 \\
\hline Coahuila & 1,543 & 1,729 & 2016 & Naturalista, 6.vii.2016 & Wallach 2020a: 78 \\
\hline Guanajuato & 1,628 & 2,022 & 2018 & iNaturalist, 14.vi.2018 & Wallach 2020a: 79 \\
\hline Colima & 15 & 502 & 2019 & iNaturalist, 20.x.2019 & Wallach 2020a: 79 \\
\hline
\end{tabular}


Table 2. Data on the invasion of the USA by Brahminy Blindsnakes (Virgotyphlops braminus) arranged chronologically from earliest to latest appearance. Columns contain the state, followed by the number of known counties, the known minimum (Min.) and maximum (Max.) elevation in meters, the first date it was observed or reported, the earliest known museum voucher, and the reference of its first verified publication.

\begin{tabular}{lcrrlll} 
& & \multicolumn{2}{c}{ Elevation } & First & Earliest & First \\
State & Counties & Min. & Max. & Date & Voucher & Publication \\
\hline Hawaii & 6 & 0 & 3,049 & 1927 & BPBM 1588 & Slevin 1930: 158 \\
\hline Florida & 42 & 0 & 57 & 1979 & AUM 32681 & Wilson and Porras 1983: 55 \\
\hline Ohio & 1 & 202 & 202 & $1985-89$ & CMNH 12074 & OPLIN 2003: 1 \\
\hline Massachusetts & 3 & 8 & 305 & 1990 & MCZ 191202 & Wallach et al. 1991: 68 \\
\hline Louisiana & 5 & 0 & 11 & 1993 & LSUMZ 56317 & Thomas 1994: 34 \\
\hline North Carolina & 1 & 105 & 105 & 1994 & NCSM 78302 & Beane et al. 2010: 6 \\
\hline Texas & 12 & 1 & 204 & $1998-99$ & TCWC 84546 & Bartlett 1998: 38 \\
\hline Virginia & 2 & 11 & 50 & 2000 & USNM 546147-51 & Savitsky et al. 2002: 150-151 \\
\hline California & 6 & 16 & 194 & 2000 & CAS 244221 & Palmer and Fisher 2010: 518 \\
\hline Arizona & 3 & 330 & 724 & 2002 & MCZ 189083 & Servoss et al. 2013: 477 \\
\hline Minnesota & 1 & 256 & 256 & 2004 & ? & Hahn 2004: 1 \\
\hline Georgia & 6 & 4 & 111 & 2005 & GMNH 50035-41 & Jensen 2007: 490 \\
\hline Alabama & 2 & 18 & 30 & 2005 & ? JSU & Mitchell 2017: 1-2 \\
\hline D.C. & 1 & 30 & 30 & $2010-15$ & $?$ & Murphy 2015: 128 \\
\hline South Carolina & 1 & 2 & 2 & 2017 & iNaturalist, 14.viii.17 & Wallach 2020a: 79 \\
\hline Maryland & 1 & 127 & 127 & 2018 & HM 239347 & Wallach 2020a: 79 \\
\hline Mississippi & 1 & 248 & 284 & 2020 & MMNS & Wallach 2020a: 79
\end{tabular}

AUM = Auburn University Museum of Natural History, $\mathrm{CIB}=$ Centro de Investigaciones Biológicas, Universidad Autónoma del Estado de Hidalgo, CIIDRUD = Centro Interdisciplinario de Investigación para el Desarrollo Regional, Unidad Durango, ECO = El Colegio de la Frontera Sur, Unidad Chetumal, ENCB = Escuela Nacional de Ciencias Biológicas, Instituto Politécnico Nacional, GMNH $=$ Georgia Museum of Natural History, $\mathrm{IBH}=$ Instituto de Biología, Universidad Autónoma de México, IIZD = Instituto de Investigaciones de Zonas Desérticas, Universidad Autónoma de San Luis Potosí, MCBFESI = Museo de las Ciencias Biológicas “Enrique Beltrán," FES-Iztacala, MMNS = Mississippi Museum of Natural Science, NCSM = North Carolina State Museum, SAM = Sherman A. Minton private coll., UAA = Universidad Autónoma de Aguascalientes, UABC = Universidad Autónoma de Baja California, and UCLA = University of California at Los Angeles.

The first record of Virgotyphlops braminus in the New World, dating from 1891, was based on a specimen collected by S. Silldorff in Acapulco, Guerrero, Mexico on 5 September 1891 (ZMUC 52172). It first was reported in the literature by Shreve (1938), and Taylor (1940) hypothesized that $V$. braminus was inadvertently transported to Acapulco by the Spanish galleon trade between the Philippines and Mexico.
It next was reported from Michoacán by Gadow (1913), and the earliest traceable voucher specimens are a pair collected in Carrizal on 28 January 1914 (BMNH 1914.1.28.120-121). In the succeeding century, $V$. braminus has been reported from all 32 states in Mexico (Table 1 lumps the newly recognized state of Mexico City together with the Distrito Federal where it was previously administered). Maximum known elevations are in Morelos at 2,620 m, in the Distrito Federal at 2,376 m, in México at 2,367 m, in Jalisco at 2,414 m, in Puebla at 2,150 m, and in Guanajuato at 2,022 m. Not surprisingly, the lowest maximum elevations occur in the Yucatan Peninsula with $3 \mathrm{~m}$ in Campeche, $20 \mathrm{~m}$ in Quintana Roo, and $23 \mathrm{~m}$ in Yucatán (Table 1).

Brahminy Blindsnakes have been documented from one-third of the states in the USA (Table 2). Hawaii holds the distinction for the first appearance of $V$. braminus in the USA with the importation in the 1920s of palm trees from the Philippines to landscape the Kamehameha Boys' School (now Bernice P. Bishop Museum) in Honolulu (Fisher 1948; Hunsaker and Breese 1967). The earliest voucher was collected by W.E. Bonsey on 1 October 1927 (BPBM 1588) and identification was derived from material collected by P. Gantt in January 1930 (Slevin 1930). This snake also possesses the highest recorded elevation of 3,049 $\mathrm{m}$ in Haleakala 
National Park on Maui. In the continental USA, $V$. braminus was first recognized in 1979 in Florida (AUM 32681) and the first published report followed four years later (Wilson and Porras 1983). Since then, it has dispersed to another 15 states for a presently known total of 17 , encompassing 94 counties and occurring on 33 islands (nine Hawaiian islands and 24 Keys in southern Florida).

Virgotyphlops braminus almost certainly inhabits new regions of which the scientific and lay communities are unaware. Since $V$. braminus is a fossorial, nocturnal, and extremely small serpent, it is rarely observed during the day and, because it superficially resembles an earthworm, when excavated or uncovered, it is not always recognized for the snake that it is. Closer inspection, however, will reveal smooth glossy scales, tiny eyes, a protrusible tongue, and rapid movement on a surface in a wriggling snakelike manner.

Everyone who comes across one of these snakes is urged to photograph or collect it and submit documentation to an appropriate agency (i.e., museum, online database, or social media). Due to several unique features of the snout, and other characters in combination, $V$. braminus can be positively identified from a photograph (unlike nearly all other scolecophidians that must be preserved and have their scales examined and counted under a microscope; Wallach 2020b).

\section{Acknowledgments}

Full acknowledgments of all individuals and organizations who assisted with data, photographs, and/or literature for this project are in Wallach (2020c).

\section{Literature Cited}

Alvarez, T. and S. Murillo. 1996. Nuevo registro de Ramphotyphlops braminus (Daudin, 1803) (Reptilia: Typhlopidae) en Nuevo León, México. Vertebrata Mexicana 2: 1-2.

Bañuelos-Alamillo, J.A. and R.A. Carbajal-Márquez. 2016. Distribution notes. Reptilia: Squamata (snakes). Family Typhlopidae. Indotyphlops braminus (Daudin, 1803). México: Zacatecas. Mesoamerican Herpetology 3: 204.

Bartlett, R.D. 1998. Herping in Texas, the sequel: Bartlett returns. Reptiles Magazine 6: 32-38.

Beane, J.C., A.L. Braswell, J.C. Mitchell, W.M. Palmer, and J.R. Harrison III. 2010. Amphibians \& Reptiles of the Carolinas and Virginia. Second edition. The University of North Carolina Press, Chapel Hill, North Carolina.

Bomford, M., F. Kraus, S. Barry, and E. Lawrence. 2009. Predicting establishment success for alien reptiles and amphibians: a role for climate matching. Biological Invasions 11: 713-724.

Campbell, H.W. and R.S. Simmons. 1962. Notes on some reptiles and amphibians from western Mexico. Bulletin of the Southern California Academy of Sciences 61: 193-203.

Campillo-García, G. 2013. Lista actualizada y analysis de la distribución de la herpetofauna en San Luis Potosí, México. Doctoral Dissertation, Escuela Nacional de Ciencias Biológicas, Instituto Politécnico Nacional, Ciudad de México, México.

Carbajal-Márquez, R.A., F. González-Quiñones, and G.E. Quintero-Díaz. 2015. Geographic distribution. Indotyphlops braminus (Brahminy Blindsnake). Herpetological Review 46: 573.

Cedeño-Vázquez, J.R., R. Calderón, and C. Pozo. 2003. New distributional records for amphibians and reptiles from Quintana Roo on the Yucatán Peninsula, México. Herpetological Review 34: 393-395.

Cervantes, B.M. de and S.A. Minton. 1975. Geographic distribution. Typhlops braminus (Brahminy blind snake). Herpetological Review 6: 117

Cuvier, G.L.C.F.D. 1828. Le règne animal distribué d'après son organisation, pour servir de base a l'histoire naturelle des animaux, et d'introduction a l'anatomie comparée. Fortin, Masson et Companie, Paris, France.

Daudin, F.M. 1803. Histoire naturelle génerale et particulière des reptiles. Tome septième. F. Dufart, Paris, France.

Dixon, J.R. and F.S. Hendricks. 1979. The wormsnakes (family Typhlopidae) of the Neotropics, exclusive of the Antilles. Zoologische Verhandelingen 173: 1-39.

Dundee, H.A. and O. Flores-Villela. 1991. Geographic distribution. Ramphotyphlops braminus (Brahminy Blind Snake). Herpetological Review 22: 26.

Eliosa-León, H., L. Canseco-Márquez, and G. Yanez-Gómez. 1995. Geographic distribution. Ramphotyphlops braminus (Braminy Blind Snake). Herpetological Review 26: 110.

Farr, W.L., D. Lazcano, and P.A. Lavín-Murcio. 2013. New distributional records for amphibians and reptiles from the state of Tamaulipas, México III. Herpetological Review 44: 631-645.

Fisher, H.I. 1948. Locality records of Pacific island reptiles and amphibians. Copeia 1948: 69 .

Grace, R.C. and M.S. Grace. 2015. Evolution of nervous system function and behavior in a micro-vertebrate, the Brahminy blindsnake (Ramphotyphlops brahminus), p. 132. In: M.L. Crump (ed.), Abstracts for the 2015 Joint Meeting of Ichthyologists and Herpetologists (16-19 July 2015), Reno, Nevada.

Guzmán, A.F. and R. Muñiz-Martínez. 1999. Primer registro de Ramphotyphlops braminus (Daudin, 1803) (Reptilia: Typhlopidae) para el estado de Durango, México. Vertebrata Mexicana 5: 1-3.

Hahn, J. 2004. Brahminy blind snake. Yard \& Garden Line News, University of Minnesota Extension 6: 1.

Hedges, S.B., A.B. Marion, K.M. Lipp, J. Marin, and N. Vidal. 2014. A taxonomic framework for typhlopid snakes from the Caribbean and other regions (Reptilia, Squamata). Caribbean Herpetology 49: 1-61.

Hernández-Ríos, A. and R.G. Trejo-Perez. 2012. Geographic distribution. Ramphotyphlops braminus (Brahminy blindsnake). Herpetological Review 43: 622.

Hernández-Salinas, U. and A. Ramírez-Bautista. 2010. Geographic distribution. Ramphotyphlops braminus (Brahminy Blind Snake). Herpetological Review 41: 519.

Hunsaker, D., Jr. and P. Breese. 1967. Herpetofauna of the Hawaiian Islands. Pacific Science 21: 423-428.

Jensen, J.B. 2007. Geographic distribution. Ramphotyphlops braminus (Braminy Blindsnake). Herpetological Review 38: 490.

Mahoney, P.J., K.H. Beard, A.M. Durso, A.G. Tallian, A.L. Long, R.J. Kindermann, N.E. Nolan, D. Kinka, and H.E. Mohn. 2015. Introduction effort, climate matching and species traits as predictors of global establishment success in non-native reptiles. Diversity and Distributions 21: 64-74.

Mancilla-Moreno, M. and A. Ramirez-Bautista. 1998. Geographic distribution. Ramphotyphlops braminus (Brahminy Blind Snake). Herpetological Review 29: 54.

McDowell, S.B. 1974. A catalogue of the snakes of New Guinea and the Solomons, with special reference to those in the Bernice P. Bishop Museum, Part I. Scolecophidia. Journal of Herpetology 8: 1-57.

Mendoza-Quijano, F., M. Mancilla-Moreno, and A. Rendon-Rojas. 1993. Geographic distribution. Ramphotyphlops braminus (Braminy Blind Snake). Herpetological Review 24: 110.

Mendoza-Quijano, F., A. Rendon-Rojas, and D.G. Mink. 1994. Geographic distribution. Ramphotyphlops braminus (Braminy Blind Snake). Herpetological Review 25: 34

Mitchell, J. 2017. Invasssssive snake found by JSU student. The Chanticleer, Jacksonville State University (13 April 2017): 1-2.

Murphy, J.B. 2015. Studies on non-venomous colubrid snakes and a few other families in zoos and aquariums. Herpetological Review 46: 119-134.

Murphy, R.W. and J.R. Ottley. 1979. Geographic distribution. Ramphotyphlops braminus (Asian Blind Snake). Herpetological Review 10: 119.

OPLIN (Ohio Public Library Information Network). 2003. Brahminy blind snake (Ramphotyphlops braminus): appearance, range, lifestyle, links (updated). Ohio Public Library Information Network \& Ohio Historical Society, Columbus, Ohio.

Palmer, D.D. and R.N. Fisher. 2010. Geographic distribution. Ramphotyphlops braminus (Brahminy Blind Snake). Herpetological Review 41: 518.

Paradiz-Dominguez, M. 2016. Geographic distribution. Indotyphlops braminus (Flowerpot snake). Herpetological Review 47: 630. 
Paz-Gutiérrez, J.G., C. Soto-Rojas, and J. Alvarado-Díaz. 2008. Geographic distribution. Ramphotyphlops braminus (Brahminy blindsnake). Herpetological Review 39: 373.

Quijada-Mascareñas, A. and L. Canseco-Márquez. 2007. Geographic distribution. Ramphotyphlops braminus (Braminy Blindsnake). Herpetological Review 38: 490.

Quijada-Mascareñas, A. and E.F. Enderson. 2007. Geographic distribution. Ramphotyphlops braminus (Braminy Blindsnake). Herpetological Review 38: 490.

Robb, J. 1966. The generic status of the Australasian typhlopids (Reptilia: Squamata). Annals and Magazine of Natural History (Ser. 13) 9: 675-679.

Russell, P. 1796. An Account of Indian Serpents, Collected on the Coast of Coromandel. George Nicol, London, England.

Savitzky, B.A., A.H. Savitzky, R.T. Belcher, and S. Ewers. 2002. Geographic distribution. Ramphotyphlops braminus (Brahminy Blindsnake). Herpetological Review 33: 150-151.

Servoss, J.M., S. Sferra, T.R. Jones, M.J. Sredl, and P.C. Rosen. 2013. Geographic distribution. Ramphotyphlops braminus (Brahminy blindsnake). Herpetological Review 44: 477.

Shreve, B. 1938. Typhlops braminus in Mexico. Herpetologica 1: 144.

Slevin, J.R. 1930. A note on the discovery of the genus Typhlops in the Hawaiian Islands. Copeia 1930: 158.

Smith, H.M. and E.H. Taylor. 1945. An annotated checklist and key to the snakes of Mexico. Bulletin of the U.S. National Museum 187: 1-239.

Solano-Zavaleta, I., U.O. García-Vazquez, and L. Canseco-Márquez. 2006. Geographic distribution. Ramphotyphlops braminus (Braminy blindsnake). Herpetological Review 37: 500.

Taylor, E.H. 1940 ("1939”). Mexican snakes of the genus Typhlops. The University of Kansas Science Bulletin 26: 441-444.

Thomas, R.A. 1994. Geographic distribution. Ramphotyphlops braminus (Braminy
Blind Snake). Herpetological Review 25: 34.

Valdespino, C.S. and R. García-Collazo. 2000. Geographic distribution. Ramphotyphlops braminus (Brahminy Blind Snake). Herpetological Review 31: 186.

Valdez-Villavicencio, J.H., A. Peralta-García, and H. Yee-Pérez. 2016. Distribution notes. Indotyphlops braminus (Daudin, 1803). Mesoamerican Herpetology 3: 205.

Vázquez-Díaz, J. and G.E. Quintero-Díaz. 2001. Geographic distribution. Ramphotyphlops braminus (Brahminy Blind Snake). Herpetological Review 32: 279.

Wallach, V. 2009. Ramphotyphlops braminus (Daudin): a synopsis of morphology, taxonomy, nomenclature and distribution (Serpentes: Typhlopidae). Hamadryad 34: 34-61.

Wallach, V. 2020a. New country and state records for Indotyphlops braminus (Serpentes: Typhlopidae). Part II. Bulletin of the Chicago Herpetological Society 55: 77-81.

Wallach, V. 2020b. How to easily identify the flowerpot snake, Indotyphlops braminus (Daudin, 1803), with proposal of a new genus (Serpentes: Typhlopidae). Pod@rcis 11:4-12.

Wallach, V. 2020c. A synopsis of geographic distribution, habitat elevation, and chronological dispersal of Indotyphlops braminus (Daudin, 1803) around the world (Serpentes: Typhlopidae). Herpetological Review 51: in press.

Wallach, V., G.S. Jones, and R.R. Kunkel. 1991. Geographic distribution. Ramphotyphlops braminus (Braminy Blind Snake). Herpetological Review 22: 68.

Wallach, V., K.L. Williams, and J. Boundy. 2014. Snakes of the World: A Catalogue of Living and Extinct Species. CRC Press, Boca Raton, Florida.

Williams, K.L. and V. Wallach. 1989. Snakes of the World. Vol. I. Synopsis of Snake Generic Names. Krieger Publishing Company, Malabar, Florida.

Wilson, L.D. and L. Porras. 1983. The ecological impact of man on the South Florida herpetofauna. University of Kansas, Museum of Natural History, Special Publication 9: 1-89. 